Article

\title{
Multiplex Immunofluorescence Assay of Infiltrating Mononu-Clear Cell Subsets in Acute T-Cell-Mediated Rejection and BK Virus-Associated Nephropathy in the Allograft Kidney
}

\author{
Mee-Seon Kim ${ }^{1}{ }^{\mathbb{D}}$, Jeong-Hoon Lim ${ }^{2}{ }^{\mathbb{D}}$, Man-Hoon Han ${ }^{1}{ }^{\mathbb{D}}$, Sang-Yeob Kim ${ }^{3,4}$, Yun Jae $\mathrm{Kim}^{4}$ \\ and Yong-Jin Kim ${ }^{1, *}$
}

Citation: Kim, M.-S.; Lim, J.-H.; Han, M.-H.; Kim, S.-Y.; Kim, Y.J.; Kim, Y.-J. Multiplex Immunofluorescence Assay of Infiltrating Mononu-Clear Cell Subsets in Acute T-CellMediated Rejection and BK Virus-Associated Nephropathy in the Allograft Kidney. Diagnostics 2022, 12 , 268. https://doi.org/10.3390/

diagnostics12020268

Academic Editor: Mauro Giuseppe Mastropasqua

Received: 28 December 2021

Accepted: 19 January 2022

Published: 21 January 2022

Publisher's Note: MDPI stays neutral with regard to jurisdictional claims in published maps and institutional affiliations.

Copyright: (C) 2022 by the authors. Licensee MDPI, Basel, Switzerland. This article is an open access article distributed under the terms and conditions of the Creative Commons Attribution (CC BY) license (https:// creativecommons.org/licenses/by/ $4.0 /$ )
1 Department of Pathology, School of Medicine, Kyungpook National University, Kyungpook National University Hospital, Daegu 41944, Korea; kimm2342@gmail.com (M.-S.K.); one-many@hanmail.net (M.-H.H.)

2 Division of Nephrology, Department of Internal Medicine, School of Medicine, Kyungpook National University, Kyungpook National University Hospital, Daegu 41944, Korea; jh-lim@knu.ac.kr

3 Department of Convergence Medicine, University of Ulsan College of Medicine and Asan Medical Center, Seoul 05505, Korea; sykim3yk@amc.seoul.kr

4 Asan Institute for Life Sciences, Asan Medical Center, Seoul 05505, Korea; windkim87@gmail.com

* Correspondence: yyjjkim1@gmail.com; Tel.: +82-10-5041-7209

\begin{abstract}
Renal allograft biopsy is the gold standard procedure for diagnosis of kidney rejection via specific pathological changes. To provide a better assessment of immunologic events in acute T-cell-mediated rejection (acute TCMR) and BK virus-associated nephropathy (BKVAN) cases, we used multiplex immunofluorescence staining to identify infiltrating mononuclear cell subsets in the cortex area of transplanted kidneys. Antibodies to CD4, CD8, CD20, CD68, Foxp3, and cytokeratin were used. In cortical interstitium, CD8+ cells were significantly more prevalent in acute TCMR than BKVAN cases ( $34 \%$ vs. $22.8 \%, p=0.034)$. In medulla, CD20+ cells were significantly more prevalent in BKVAN than acute TCMR cases $(51.9 \%$ vs. $11.3 \%, p=0.028)$.
\end{abstract}

Keywords: multiplex immunofluorescence assay; image analysis; T-cell-mediated rejection; BK virus-associated nephropathy; transplant kidney

\section{Introduction}

Renal allograft biopsy is the gold standard procedure for diagnosis of kidney rejection via specific pathological changes. The major factor in acute T-cell-mediated rejection (TCMR) is tissue infiltration of mononuclear cells. Acute TCMR severity depends on the percentage of the interstitial area affected by infiltration [1-3]. T cells are known to be important in the pathogenesis of acute TCMR, although multiple other mononuclear cell subpopulations, including B cells, NK cells, plasma cells, and monocytes/macrophages, have been shown to contribute to the outcome of rejection-related immunologic events [4-7]. However, cell population analysis is complicated using traditional immunohistochemistry because of the limitations of staining using multiple antibodies and human error in cell counting $[8,9]$.

To provide a better assessment of immunologic events in acute TCMR and BK virusassociated nephropathy (BKVAN) cases, we used multiplex immunofluorescence assays to identify infiltrating mononuclear cell subsets in a transplanted kidney in cortex areas. Because BKVAN has characteristic interstitial mononuclear cell infiltration, and even tubulitis, which is one of the symbolic changes of acute TCMR, it is difficult to differentiate between the two conditions. Additionally, we tried to evaluate the differences in infiltrating cell subsets in the excluded areas for diagnosis, including fibrotic areas, the immediate subcapsular cortex, and adventitia around large vessels and medullary areas [1]. 


\section{Materials and Methods}

\subsection{Study Design}

Multiplex immunofluorescence assays of formalin-fixed, paraffin-embedded tissues (FFPE) were conducted using samples from nine patients with acute TCMR and five patients with BKVAN at various time points after transplantation. All samples were collected between 1 January 2015 and 1 December 2017 at the Department of Pathology in Kyungpook National University Hospital and Yeungnam University Medical Center in Daegu, Korea. The study protocol was approved by the Daegu Joint Institutional Review Board (DGIRB 2017-08-001), and informed consent was waived by the Daegu Joint Institutional Review Board. All methods were carried out in accordance with the Korean Bioethics and Safety Act.

\subsection{Patient Selection Criteria and Tissue Pathology Grading}

Inclusion criteria for acute TCMR $(n=9)$ were: category 4 histologic features of acute TCMR based on the Banff 2017 classification system [10]; negativity for SV-40 cells based on IHC; absence of BK virus in serum or urine; negativity for the donor-specific antibody. The male-to-female ratio of patients with TCMR was 6:3. The mean patient age and graft age were 46.8 (range, 33-62) years and 7.2 (1-15) months, respectively. Acute TCMR grades $1 \mathrm{~A}, 1 \mathrm{~B}$, and 2B were observed in three different patients. Plasma cell-rich types of TCMR were not included (Table 1$)$. Inclusion criteria for BKVAN $(n=5)$ were: histologic features of BKVAN with SV-40-positive cells in the cortex; clinical improvement in graft function with anti-viral treatment after pathologic diagnosis; no histologic features of acute TCMR or ABMR; >500 inflammatory cells in the cortical area. All BKVAN patients were male $(n=5)$. The mean patient and graft ages were $47.4(25-62)$ years and $5.1(2.5-7)$ months, respectively. According to the Banff Working Group Classification System [11], one patient had class A, three had class B, and one had class C diseases (Table 2).

Table 1. Basic data of acute TCMR cases.

\begin{tabular}{|c|c|c|c|c|c|c|}
\hline \multirow{2}{*}{ Case } & \multirow{2}{*}{ Age } & \multirow{2}{*}{ Sex } & Graft Age & Creatinine & \multirow{2}{*}{ Banff Score } & \multirow{2}{*}{ Grade } \\
\hline & & & Months & $\mathrm{mg} / \mathrm{dL}$ & & \\
\hline 1 & 42 & $\mathrm{~F}$ & 3 & 1.8 & $\mathrm{i} 2, \mathrm{t} 3, \mathrm{ptc} 1, \mathrm{ti} 2$ & $1 \mathrm{~A}$ \\
\hline 2 & 33 & M & 15 & 4.3 & $\mathrm{i} 2, \mathrm{t} 3$, ptc1, ci2, ct2 & $1 \mathrm{~B}$ \\
\hline 3 & 40 & M & 9 & 4.4 & $\mathrm{i} 3, \mathrm{t} 3, \mathrm{v} 2$ & $2 B$ \\
\hline 4 & 33 & M & 8 & 2.7 & $\mathrm{i} 2, \mathrm{t} 2, \mathrm{ptc} 1$ & $1 \mathrm{~A}$ \\
\hline 5 & 55 & M & 1 & 1.2 & $\mathrm{i} 2, \mathrm{t} 2, \mathrm{v} 2, \mathrm{ptc} 1$ & $2 \mathrm{~B}$ \\
\hline 6 & 56 & $\mathrm{~F}$ & 10 & 2.4 & $\mathrm{i} 2, \mathrm{t} 3, \mathrm{cv} 1$ & $1 \mathrm{~B}$ \\
\hline 7 & 58 & M & 4 & 2.8 & $\mathrm{i} 3, \mathrm{t} 2, \mathrm{ptc} 1, \mathrm{ti} 3$ & $1 \mathrm{~A}$ \\
\hline 8 & 62 & M & 8 & 2.4 & $\begin{array}{c}\mathrm{t} 1, \mathrm{v} 2, \mathrm{ptc1}, \mathrm{ci} 1, \mathrm{ct} 1, \mathrm{ti} 2, \\
\text { i-IFTA3 }\end{array}$ & $2 \mathrm{~B}$ \\
\hline 9 & 42 & $\mathrm{~F}$ & 7 & 4.5 & $\mathrm{i} 3, \mathrm{t} 3, \mathrm{~g} 1, \mathrm{ci} 2, \mathrm{ct} 2, \mathrm{cv} 1, \mathrm{ah} 1, \mathrm{ti} 3$ & $1 \mathrm{~B}$ \\
\hline
\end{tabular}

Table 2. Basic data of BK virus nephropathy cases.

\begin{tabular}{ccccccc}
\hline Case & Age & Sex & $\begin{array}{c}\text { Graft Age } \\
\text { Months }\end{array}$ & $\begin{array}{c}\text { Creatinine } \\
\text { mg/dL }\end{array}$ & Banff Score & Stage \\
\hline 1 & 62 & M & 5.5 & 2.2 & ci1, ct1, cv1, i-IFTA1 & $\mathrm{B}$ \\
2 & 58 & $\mathrm{M}$ & 2.5 & 1.8 & $\mathrm{i} 3, \mathrm{t} 1, \mathrm{ptc} 1, \mathrm{ti} 3$ & $\mathrm{~B}$ \\
3 & 30 & $\mathrm{M}$ & 7 & 1.8 & $\mathrm{ci} 1, \mathrm{ct} 1, \mathrm{ti} 3$ & $\mathrm{~A}$ \\
4 & 25 & $\mathrm{M}$ & 4 & 3.3 & $\mathrm{I} 2, \mathrm{ci} 1, \mathrm{ct} 1, \mathrm{ti} 3$ & $\mathrm{~B}$ \\
5 & 62 & $\mathrm{M}$ & 6.5 & 3.1 & $\mathrm{i} 2, \mathrm{ptc1}, \mathrm{ci} 2, \mathrm{ct} 3, \mathrm{ti} 3, \mathrm{i}-\mathrm{IFTA3}$ & $\mathrm{C}$ \\
\hline
\end{tabular}




\subsection{Multiplex Immunofluorescence (IF) Assay}

The formalin-fixed, paraffin-embedded (FFPE) blocks of renal biopsy specimens were cut into $2 \mu \mathrm{m}$ sections. The slides were heated for at least $1 \mathrm{~h}$ in a dry oven at $60{ }^{\circ} \mathrm{C}$ and dewaxed using Leica Bond Dewax (\#AR9222, Leica Biosystems). Then, multiplex immunofluorescence assays were performed using Leica Bond Rx Automated Stainer (Leica Biosystems, Newcastle, UK). Antigens were retrieved using Bond Epitope Retrieval 2 (\#AR9640, Leica Biosystems) in a solution at pH 9.0 for $30 \mathrm{~min}$. The slides were incubated with primary antibodies for CD8 (MCA1817T, dilution 1:300; Bio-Rad Laboratories, Hercules, CA, USA) for 30 min and then analyzed using polymer HRP Ms+Rb (ARH1001EA; PerkinElmer, Waltham, MA, USA) for $10 \mathrm{~min}$. CD8 was visualized using Opal 690 TSA Plus (dilution 1:150; $10 \mathrm{~min}$ ). To remove bound antibodies before the next step in the staining sequence, slides were treated with Bond Epitope Retrieval 1 (\#AR9961, Leica Biosystems) for $20 \mathrm{~min}$. In a serial fashion, the slides were incubated with the next primary antibodies against Foxp3 (ab20034, dilution 1:100; Abcam, Cambridge, UK) for 30 min and analyzed using Polymer HRP Ms+Rb. Foxp3 was also visualized using Opal 650 TSA Plus (dilution 1:300) for $10 \mathrm{~min}$. The same procedure was repeated for staining with anti-CD20 (ab9475, dilution 1:50; Abcam; visualized with Opal 620 TSA Plus (dilution 1:150)), anti-CD68 (M0876, dilution 1:100; Dako, Santa Clara, CA; visualized with Opal 570 TSA Plus (dilution 1:150)), anti-CD4 (ab133616, dilution 1:100; Abcam; visualized with Opal 540 TSA Plus (dilution 1:300)), and anti-CK (M3515; dilution 1:500; Dako; visualized with Opal 520 TSA Plus (dilution 1:150)) immunoreagents. After treatment with Bond Epitope Retrieval 1 for $20 \mathrm{~min}$, cell nuclei were subsequently visualized with $4^{\prime}, 6$-diamidino-2-phenylindole (DAPI) stain, and the section was cover-slipped with HIGHDEF ${ }^{\circledR}$ IHC Fluoromount (ADI-950-260-0025; Enzo Life Science, Inc., Farmingdale, NY, USA).

\subsection{Image Acquisition and Quantitative Data Analysis}

The slides were scanned using the PerkinElmer Vectra 3.0 Automated Quantitative Pathology Imaging System at $20 \mathrm{~nm}$ wavelength intervals from 420 to $720 \mathrm{~nm}$. The different depth images were combined to create a single stack image, which retained the unique spectral signature of all multiplex immunofluorescence markers. The final image files were created using Vectra and analyzed using InForm 2.2.1 and TIBCO Spotfire software (PerkinElmer). To compare reliable unmixed images, the representative images of each emission spectrum and unstained tissue slides were used. Each individually stained section (CD8-Opal 690, Foxp3-Opal 650, CD68-Opal 620, CD20-Opal 570, CD4-Opal 540, CK-Opal520, and DAPI) was used to establish the spectral library of fluorophores required for multispectral analysis. Individual cells were identified by detecting nuclear spectral elements (DAPI). For co-expression analysis, the data obtained using InForm 2.2.1 were sent to TIBCO Spotfire, and the threshold for the positivity of each marker was determined using the IHC scoring method. For each antibody, all cells in each slide were counted (positive and negative), and the data were categorized and exported to an Excel file (Microsoft Corp., Redmond, WA, USA) for analysis. The proportions of CD8-, Foxp3-, CD68-, CD20-, CD4-, and CK-positive cells in the regions of interest (ROIs) in each slide were calculated. The total number of positive cells were counted as the total immune cell infiltrations in the tissues. The percentage of each immune cell subset was calculated by dividing the absolute number of each subset by the total number of cells.

\subsection{Region of Interest (ROI)}

The ROIs were defined as follows (Figure 1): 


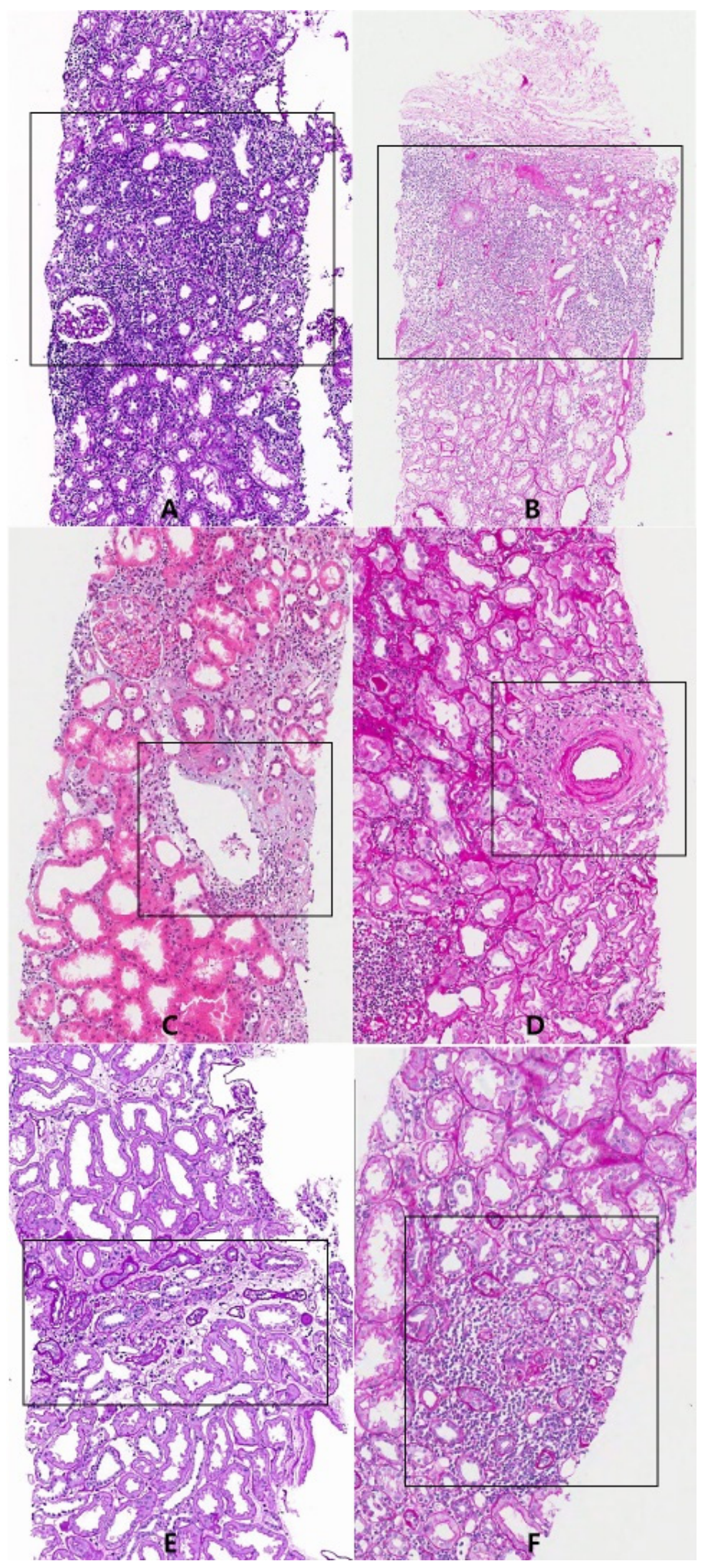

Figure 1. Representative areas of regions of interest (ROIs). (A) Cortical interstitial infiltration area (periodic acid-schiff stain, $\times 100$ ); (B) subcapsular area (periodic acid-schiff stain, $\times 100)$; (C) area surrounding the vein (hematoxylin and eosin stain, $\times 100$ ); (D) adventitia area of artery (periodic acid-schiff stain, $\times 100$ ); (E) medullary ray, longitudinal section (periodic acid-schiff stain, $\times 100$ ); (F) medullary ray, cross section (periodic acid-schiff stain, $\times 100$ ). 
Cortical interstitium: Mononuclear cell-infiltrated area in the renal cortex except the area surrounding a large vessel with no severe tubular atrophic or fibrotic changes; representative area for Banff score " $\mathrm{i}$ ".

Area surrounding large vessel: Mononuclear cell-infiltrated area around veins, arteries, or lymphatics. These areas were not considered to be not meaningful for assessment of Banff score " $\mathrm{i}$ ". We did not separate each.

Medullary ray: The area with structures consisting of bundles of renal tubules which are formed in the renal cortex and continue to run through the renal medulla as medullary striations. This area was not separated from the cortical interstitium in Banff scoring.

Medulla: Mononuclear cell-infiltrated area in the renal medulla.

Subcapsular area: The area immediately beneath the renal capsule, which may show nonspecific scarring or inflammation. The condition is thought to be related to surgical handling.

The rectangular ROIs were marked on the scanned images acquired after multiplex immunofluorescence staining (Figure 2).

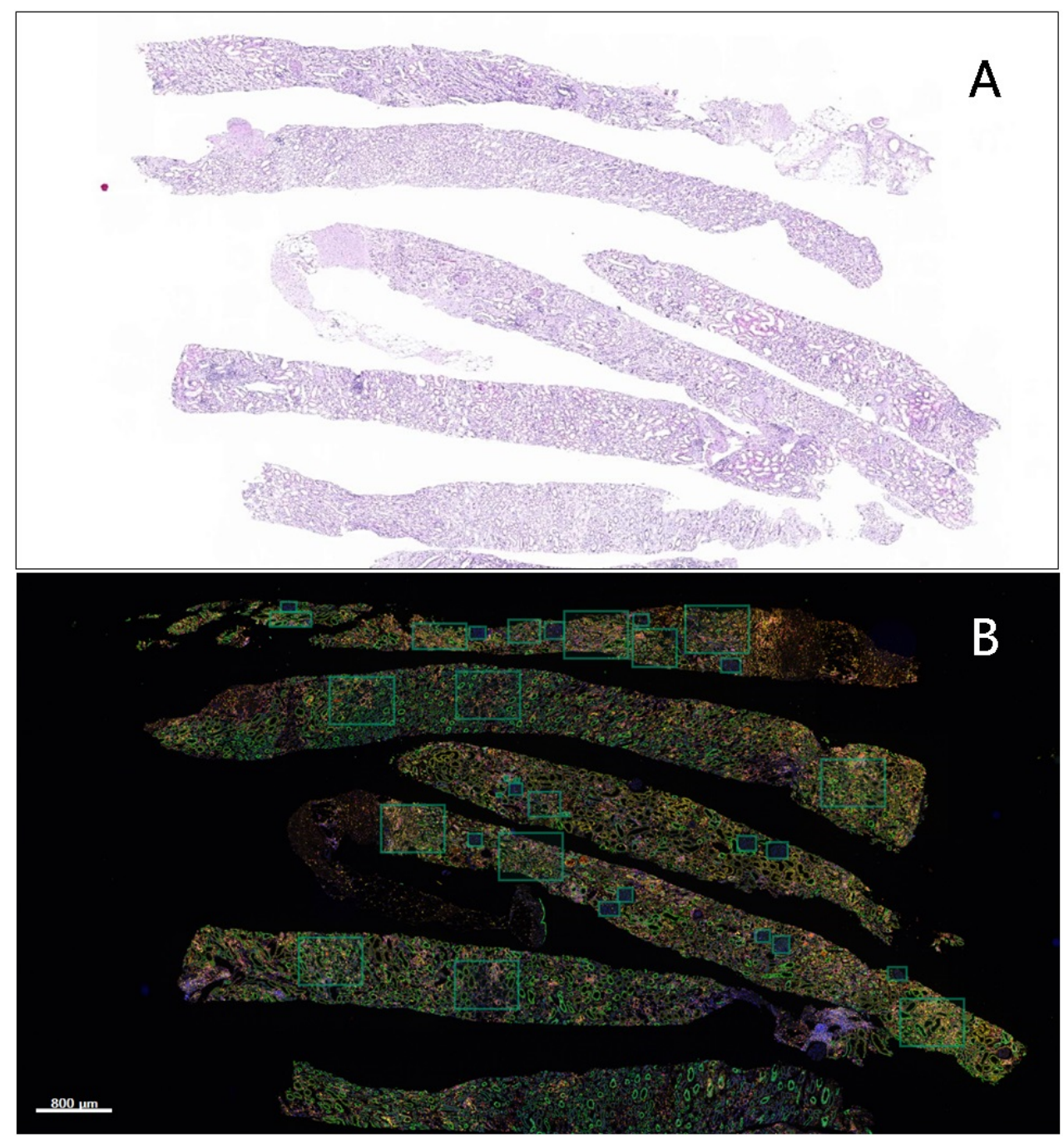

Figure 2. Selection of regions of interest (ROIs). (A) Acute T-cell-mediated rejection samples were stained with PAS; (B) the scanned images show multiplex immunofluorescence staining. ROIs are marked with rectangles. Cell counting was independently performed within these ROIs. The total number of cells was assessed per ROI.

Positive and negative cell counting was performed independently within these rectangular ROIs. Then, the total number in each rectangular ROI was assessed. Any rectangular ROI with less than a total of 100 cells was excluded (Figure 3). 


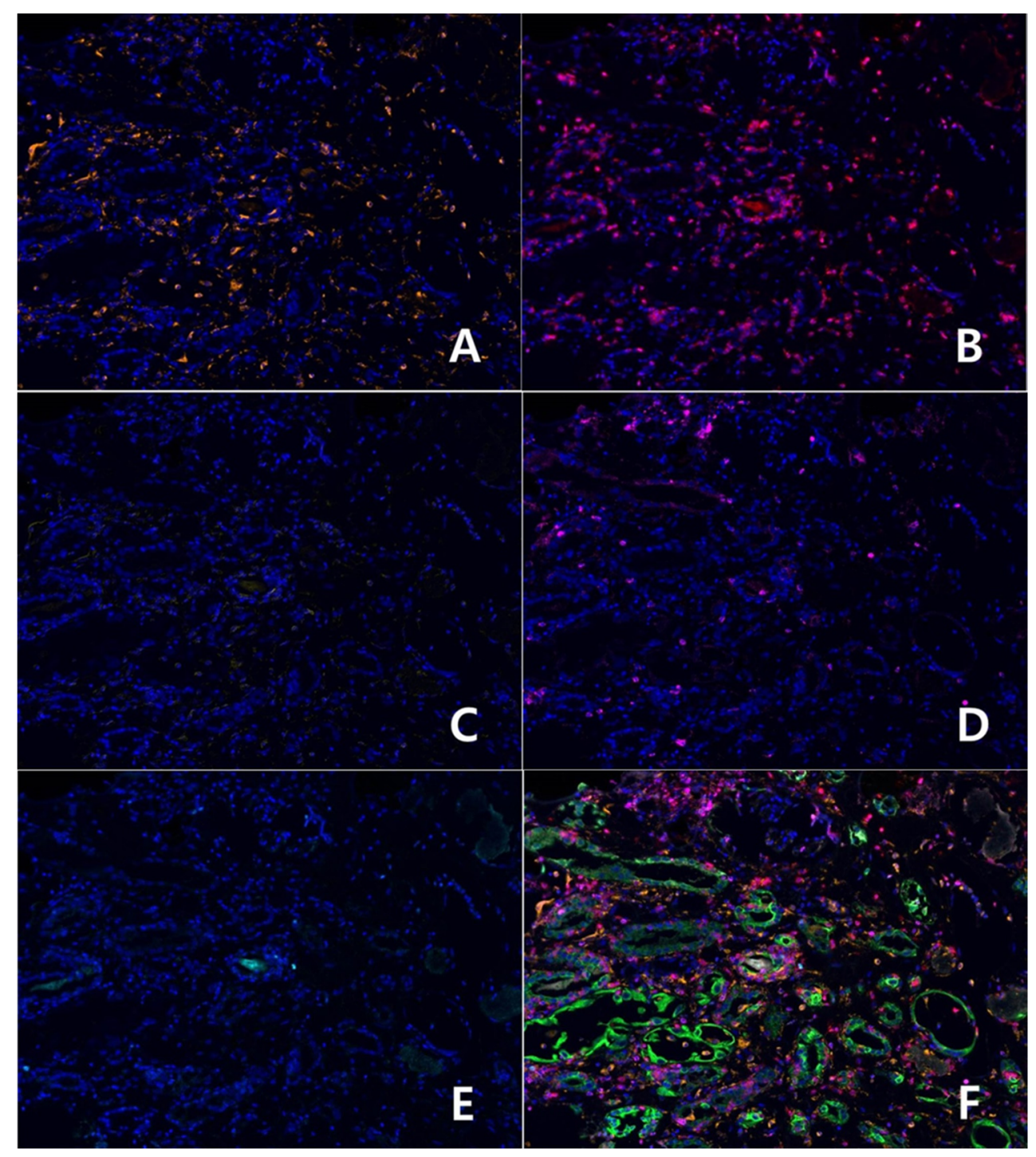

Figure 3. Multiplex immunofluorescent images show the individual antibody staining as follows (×200): (A) CD68+(Opal 620); (B) CD8+(Opal 690); (C) CD20+(Opal 570); (D) CD4+(Opal 540); (E) Foxp3+(Opal 650); (F) Antibody staining was merged with cytokeratin (CK, Opal 520) staining. Blue nuclear stain represents $4^{\prime}$,6-diamidino-2-phenylindole (DAPI).

In acute TCMR cases $(n=9)$, the cortical interstitium $(n=16)$, area surrounding a large vessel $(n=13)$, medullary ray $(n=8)$, medulla $(n=10)$, and subcapsular area $(n=3)$ were selected for evaluation. In BKVAN cases $(n=5)$, the cortical interstitium $(n=12)$, area surrounding a large vessel $(n=3)$, medullary ray $(n=2)$, medulla $(n=3)$, and subcapsular area $(n=3)$ were selected for evaluation.

\subsection{Statistical Analysis}

The analyses were performed using $\mathrm{R}$ version 4.1.2. (The R Foundation for Statistical Computing; Auckland, New Zealand). The difference between mononuclear cell subsets in relation to different regions of interest (ROIs) for acute TCMR and BKVAN cases was calculated using the Kruskal-Wallis rank sum test. The difference of mononuclear cell subsets between acute TCMR and BKVAN was calculated using the Wilcoxon rank sum test. Kendall's rank correlation test was performed to evaluate the association between graft age and mononuclear cell proportion in acute TCMR cases. Statistical analysis could not be performed for the subscapular area because of the small number of samples. 


\section{Results}

The proportions of mononuclear cell subsets in different regions of interest (ROIs) are presented and compared in terms of various aspects of acute TCMR and BKVAN infiltrations in Table 3.

Table 3. Median mononuclear cell subset numbers and ratios counted in regions of interest (ROI) and assessed using five monoclonal antibodies in nine cases of acute T-cell-mediated rejection (Acute TCMR) and five cases of BK virus-associated nephropathy (BKVAN).

\begin{tabular}{|c|c|c|c|c|c|c|c|c|}
\hline & Acute TCMR & Acute TCMR & Acute TCMR & Acute TCMR & BKVAN & BKVAN & BKVAN & BKVAN \\
\hline & $\begin{array}{c}\text { Cortical } \\
\text { Interstitium }\end{array}$ & $\begin{array}{l}\text { Medullary } \\
\text { Ray }\end{array}$ & Medulla & $\begin{array}{c}\text { Area } \\
\text { Surrounding } \\
\text { Large Vessel }\end{array}$ & $\begin{array}{c}\text { Cortical } \\
\text { Interstitium }\end{array}$ & Medullary Ray & Medulla & $\begin{array}{c}\text { Area } \\
\text { Surrounding } \\
\text { Large Vessel }\end{array}$ \\
\hline & $(n=16)$ & $(n=8)$ & $(n=10)$ & $(n=13)$ & $(n=12)$ & $(n=2)$ & $(n=3)$ & $(n=3)$ \\
\hline Count & Median (IQR) & Median (IQR) & Median (IQR) & Median (IQR) & Median (IQR) & Median (IQR) & Median (IQR) & Median (IQR) \\
\hline CD68 & $\begin{array}{c}345.5 \\
(111.0-868.8)\end{array}$ & $\begin{array}{c}284 \\
(58.5-404.5)\end{array}$ & $\begin{array}{c}365.5 \\
(125.5-1242.0)\end{array}$ & $\begin{array}{c}283 \\
(102.0-501.0)\end{array}$ & $\begin{array}{c}552 \\
(82.0-955.0)\end{array}$ & $\begin{array}{c}275 \\
(151.5-398.5)\end{array}$ & $\begin{array}{c}913 \\
(776.5-1538.0)\end{array}$ & $\begin{array}{c}335 \\
(223.5-695.5)\end{array}$ \\
\hline CD8 & $\begin{array}{c}316.5 \\
(80.5-600.3) \\
\end{array}$ & $\begin{array}{c}252 \\
(69.5-496.5) \\
\end{array}$ & $\begin{array}{c}410 \\
(195.0-1919.0) \\
\end{array}$ & $\begin{array}{c}322 \\
(132.0-691.5) \\
\end{array}$ & $\begin{array}{c}321.5 \\
(42.5-1041.0) \\
\end{array}$ & $\begin{array}{c}486 \\
(329-643) \\
\end{array}$ & $\begin{array}{c}552 \\
(468.5-1990.5) \\
\end{array}$ & $\begin{array}{c}1522 \\
(762-1604.5) \\
\end{array}$ \\
\hline $\mathrm{CD} 4$ & $\begin{array}{c}8 \\
(1.0-30.8)\end{array}$ & $\begin{array}{c}0 \\
(0-160.3)\end{array}$ & $\begin{array}{c}43 \\
(5.0-147.3)\end{array}$ & $\begin{array}{c}2 \\
(0-51.5)\end{array}$ & $\begin{array}{c}61 \\
(2.3-697.5)\end{array}$ & $\begin{array}{c}126 \\
(69.5-182.5)\end{array}$ & $\begin{array}{c}24 \\
(12-240)\end{array}$ & $\begin{array}{c}226 \\
(113.5-504.5)\end{array}$ \\
\hline FOXP3 & $\begin{array}{c}39.5 \\
(4.8-69.8)\end{array}$ & $\begin{array}{c}32.5 \\
(11.0-55.3)\end{array}$ & $\begin{array}{c}27.5 \\
(7.5-285.8)\end{array}$ & $\begin{array}{c}49 \\
(19.5-109.5)\end{array}$ & $\begin{array}{c}21 \\
(3.5-623.3)\end{array}$ & $\begin{array}{c}190.5 \\
(117.75-263.25)\end{array}$ & $\begin{array}{c}68 \\
(43-175)\end{array}$ & $\begin{array}{c}197 \\
(99-1860)\end{array}$ \\
\hline CD20 & $\begin{array}{c}137 \\
(27.5-476.0)\end{array}$ & $\begin{array}{c}370 \\
(11.5-488.0)\end{array}$ & $\begin{array}{c}209.5 \\
(26.8-423.8)\end{array}$ & $\begin{array}{c}210 \\
(69.5-872.0)\end{array}$ & $\begin{array}{c}329.5 \\
(39.5-689.8)\end{array}$ & $\begin{array}{c}93 \\
(59.5-126.5)\end{array}$ & $\begin{array}{c}1423 \\
(1391.5-1430.5)\end{array}$ & $\begin{array}{c}900 \\
(501-1524)\end{array}$ \\
\hline Total & $\begin{array}{c}902.5 \\
(276.8-2117.5)\end{array}$ & $\begin{array}{c}1172 \\
(179.0-1906.3)\end{array}$ & $\begin{array}{c}1127 \\
(304.3-4583.8)\end{array}$ & $\begin{array}{c}1111 \\
(374.5-2171.0)\end{array}$ & $\begin{array}{c}1753 \\
(205.8-4286.5)\end{array}$ & $\begin{array}{c}1170.5 \\
(985.75-1355.25)\end{array}$ & $\begin{array}{c}2739 \\
(2730.5-5214.5)\end{array}$ & $\begin{array}{c}4066 \\
(2142-6188.5)\end{array}$ \\
\hline Ratio & Median (IQR) & Median (IQR) & Median (IQR) & Median (IQR) & Median (IQR) & Median (IQR) & Median (IQR) & Median (IQR) \\
\hline CD68 (\%) & $\begin{array}{c}41.8 \\
(31.7-46.9) \\
\end{array}$ & $\begin{array}{c}21.2 \\
(19.3-30.9) \\
\end{array}$ & $\begin{array}{c}36.8 \\
(21.0-42.8) \\
\end{array}$ & $\begin{array}{c}26.9 \\
(18.1-34.2) \\
\end{array}$ & $\begin{array}{c}40.1 \\
(23.4-48.7) \\
\end{array}$ & $\begin{array}{c}18.7 \\
(11.1-26.3) \\
\end{array}$ & $\begin{array}{c}28.1 \\
(25.8-30.7) \\
\end{array}$ & $\begin{array}{c}26 \\
(15-38.7) \\
\end{array}$ \\
\hline CD8 (\%) & $\begin{array}{c}34 \\
(24.7-45.1)\end{array}$ & $\begin{array}{c}38.2 \\
(18.3-41.8)\end{array}$ & $\begin{array}{c}41.2 \\
(30.3-46.2)\end{array}$ & $\begin{array}{c}31.6 \\
(18.5-39.2)\end{array}$ & $\begin{array}{c}22.8 \\
(13.6-30.3)\end{array}$ & $\begin{array}{c}36.7 \\
(29.1-44.3)\end{array}$ & $\begin{array}{c}20.3 \\
(17.2-32.4)\end{array}$ & $\begin{array}{c}18.3 \\
(9.6-29.9)\end{array}$ \\
\hline CD4 (\%) & $\begin{array}{c}1.3 \\
(0.2-6.6)\end{array}$ & $\begin{array}{c}0 \\
(0-14.5)\end{array}$ & $\begin{array}{c}1.7 \\
(0.7-21.7)\end{array}$ & $\begin{array}{c}0.4 \\
(0-1.8)\end{array}$ & $\begin{array}{c}3.4 \\
(0.7-32.3)\end{array}$ & $\begin{array}{c}15.3 \\
(8.1-22.6)\end{array}$ & $\begin{array}{c}0.9 \\
(0.4-3.4)\end{array}$ & $\begin{array}{c}5.6 \\
(3-7.5)\end{array}$ \\
\hline$\underset{(\%)}{\mathrm{FOXP3}}$ & $\begin{array}{c}2.7 \\
(1.5-6.8)\end{array}$ & $\begin{array}{c}2.5 \\
(1.3-20.1)\end{array}$ & $\begin{array}{c}4 \\
(1.1-6.1)\end{array}$ & $\begin{array}{c}5.7 \\
(3.4-15.2)\end{array}$ & $\begin{array}{c}1.7 \\
(1.2-15.7)\end{array}$ & $\begin{array}{c}22.4 \\
(12.7-32.2)\end{array}$ & $\begin{array}{c}2.5 \\
(1.6-3.1)\end{array}$ & $\begin{array}{c}4.8 \\
(2.7-23.6)\end{array}$ \\
\hline CD20 (\%) & $\begin{array}{c}11.3 \\
(3.7-23.1)\end{array}$ & $\begin{array}{c}21 \\
(8.5-34.3)\end{array}$ & $\begin{array}{c}11.3 \\
(5.2-16.8)\end{array}$ & $\begin{array}{c}32.6 \\
(18.8-41.8)\end{array}$ & $\begin{array}{c}16.4 \\
(7.2-25.3)\end{array}$ & $\begin{array}{c}6.8 \\
(5-8.6)\end{array}$ & $\begin{array}{c}51.9 \\
(34.8-52.4)\end{array}$ & $\begin{array}{c}25.8 \\
(24-36.3)\end{array}$ \\
\hline
\end{tabular}

3.1. The Proportions of Mononuclear Cell Subsets in Acute TCMR Cases in Relation to Different Regions of Interest (ROIs)

In acute TCMR cases, the cortical interstitium $(n=16)$, area surrounding a large vessel $(n=13)$, medullary ray $(n=8)$, and medulla $(n=10)$ were selected as ROIs for the analysis. The subcapsular area $(n=3)$ was excluded from the analysis because of the small number of samples. In the cortical interstitium, the most frequently observed cells were CD68+ cells (41.8\%; Table 3), followed by CD8+, CD20+, Foxp3, and CD4+. In the medullary rays, the most frequently observed cells were CD8+ (38.2\%; Table 3$)$, followed by CD68+, CD20+, Foxp3, and CD4+ cells. In the medulla, the most frequently observed cells were CD8+ (41.2\%; Table 3), followed by CD68+, CD20+, Foxp3, and CD4+ cells. In the area surrounding a large vessel, the most frequently observed cells were CD20+ (32.6\%; Table 3$)$, followed by CD8+, CD68+, Foxp3, and CD4+ cells. The CD68+ cell had a significantly higher prevalence in cortical interstitium and medulla areas than the medullary ray or area surrounding a large vessel $(41.8 \%, 36.8 \%$ vs. $21.2 \%, 26.9 \% p=0.0165$; Table 3$)$. The proportion of CD20+ cells differed significantly between regions of interest $(p=0.0024$; Table 3). The CD20+ cell had a significantly higher prevalence in the area surrounding a large vessel than the other ROIs (32.6\% vs. $11.3 \%, 21.0 \%$; Table 3 ).

\subsection{The Proportions of Mononuclear Cell Subsets in BKVAN Cases in Relation to Different Regions of Interest (ROIs)}

In BKVAN cases $(n=5)$, the cortical interstitium $(n=12)$, area surrounding a large vessel $(n=3)$, medullary ray $(n=2)$, and medulla $(n=3)$ areas were selected as ROIs 
for comparison with acute TCMR cases. In the cortical interstitium, the most frequently observed cells were CD68+ cells (40.1\%; Table 3), followed by CD8+ (22.8\%), CD20+ (16.4\%), $\mathrm{CD} 4+(3.4 \%)$, and FOXP3+ cells $(1.7 \%)$. In the medullary rays, the most frequently observed cells were CD8+ (36.7\%; Table 3), followed by FOXP3+ (22.4\%), CD68+ (18.7\%), CD4+ $(15.3 \%)$, and CD20+ cells $(6.8 \%)$. In the medulla, the most frequently observed cells were CD20+ (51.9\%; Table 3), followed by CD68+ (28.1\%), CD8+ (20.3\%), FOXP3+ $(2.5 \%)$, and $\mathrm{CD} 4+$ cells $(0.9 \%)$. In the area surrounding a large vessel, the most frequently observed cells were CD68+ (26\%; Table 3), followed by CD8+ (25.8\%), CD8+ (18.3\%), CD4+ (5.6\%), and FOXP3+ cells $(4.8 \%)$. The CD20+ cell had a significantly higher prevalence in the medulla $(51.9 \%)$ when compared with other ROIs. The proportion of CD20+ cells in ROI also differed significantly between areas $(p=0.049$; Table 3$)$.

\subsection{The Proportions of Mononuclear Cell Subsets in Acute TCMR versus BKVAN cases}

In the cortical interstitium, CD8+ cells were significantly more prevalent in acute TCMR cases than BKVAN cases ( $34 \%$ vs. $22.8 \%, p=0.034$; Table 3 and Figure 4 ). In the medullary ray, there was no significant difference between acute TCMR and BKVAN cases with respect to the proportion of mononuclear subsets. (Table 3 and Figure 5). In the medulla, CD20+ cells were significantly more prevalent in BKVAN cases than acute TCMR cases $(51.9 \%$ vs. $11.3 \%, p=0.028$; Table 3 and Figure 6$)$. In the area surrounding a large vessel, there was no significant difference between acute TCMR and BKVAN cases with respect to the proportion of mononuclear subsets. (Table 3 and Figure 7).

\section{Mononuclear Cell Subsets in Cortical Interstitium}

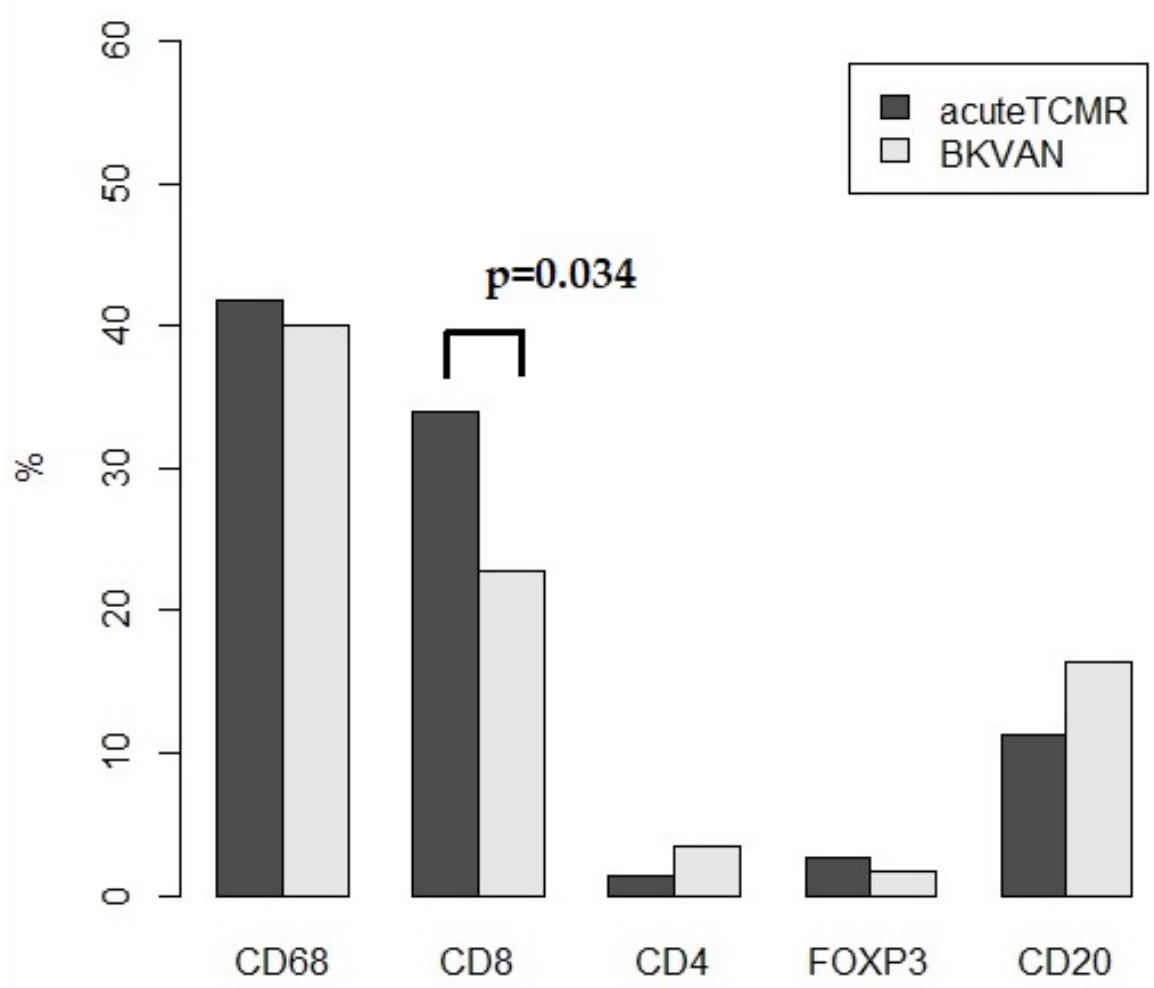

Figure 4. The proportions of mononuclear cell subsets for acute TCMR versus BKVAN cases in cortical interstitium. CD8+ cells were significantly more prevalent in TCMR than BKVAN cases $(p=0.034)$. 
Mononuclear Cell Subsets in Medullary Ray

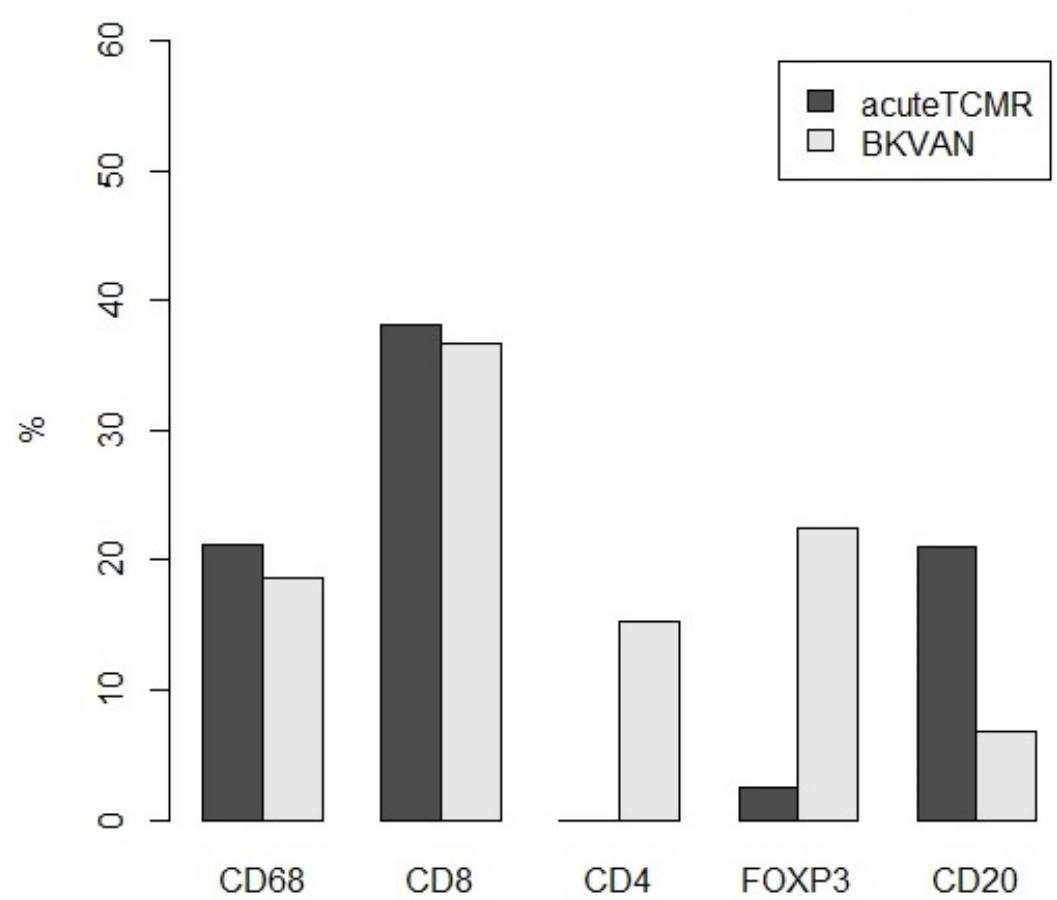

Figure 5. The proportions of mononuclear cell subsets for acute TCMR versus BKVAN cases in medullary ray.

\section{Mononuclear Cell Subsets in Medulla}

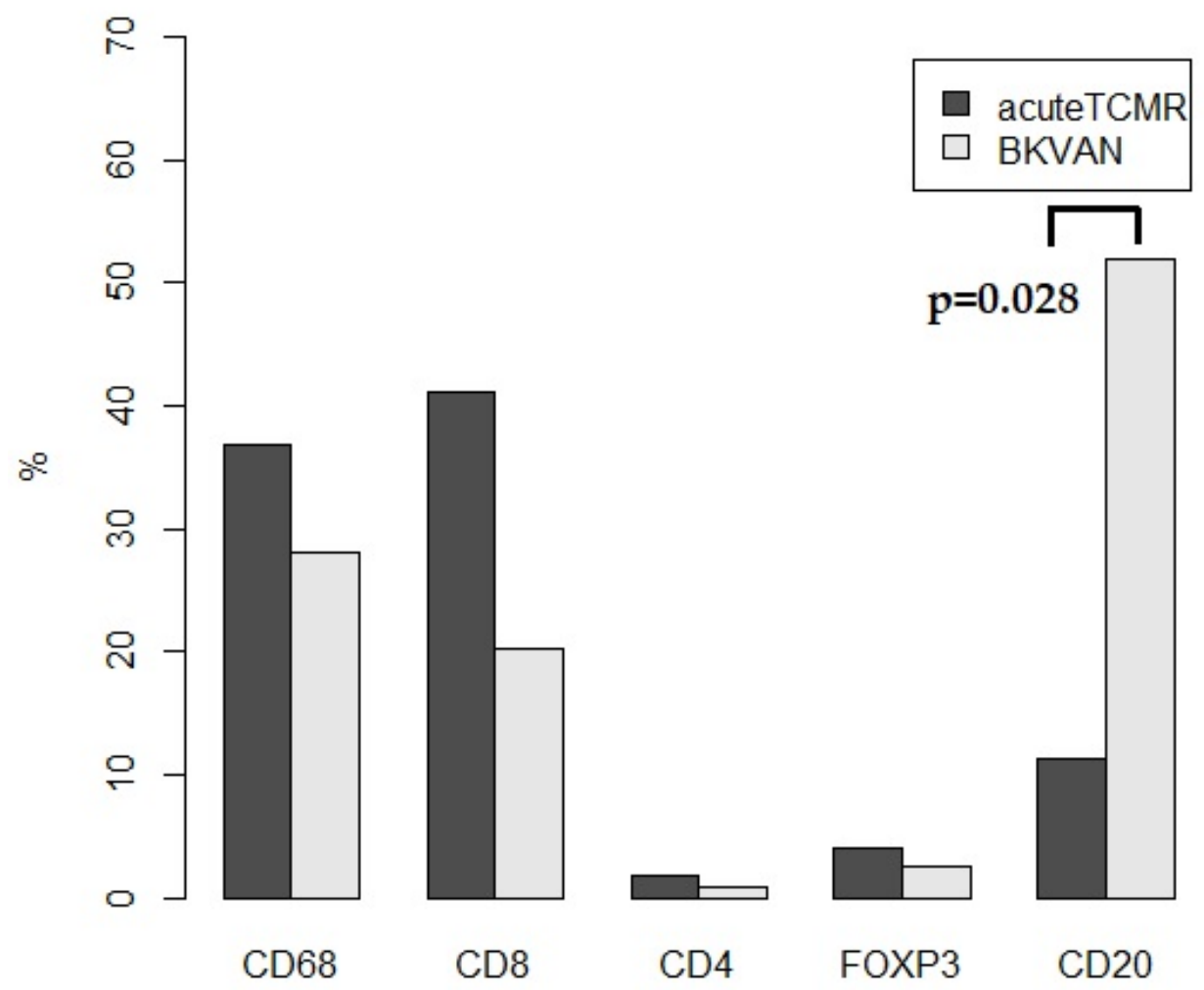

Figure 6. The proportions of mononuclear cell subsets for acute TCMR versus BKVAN cases in medulla. CD20+ cells were significantly more prevalent in BKVAN than TCMR cases $(p=0.028)$. 


\section{Mononuclear Cell Subsets in Surrounding a Large Vessel}

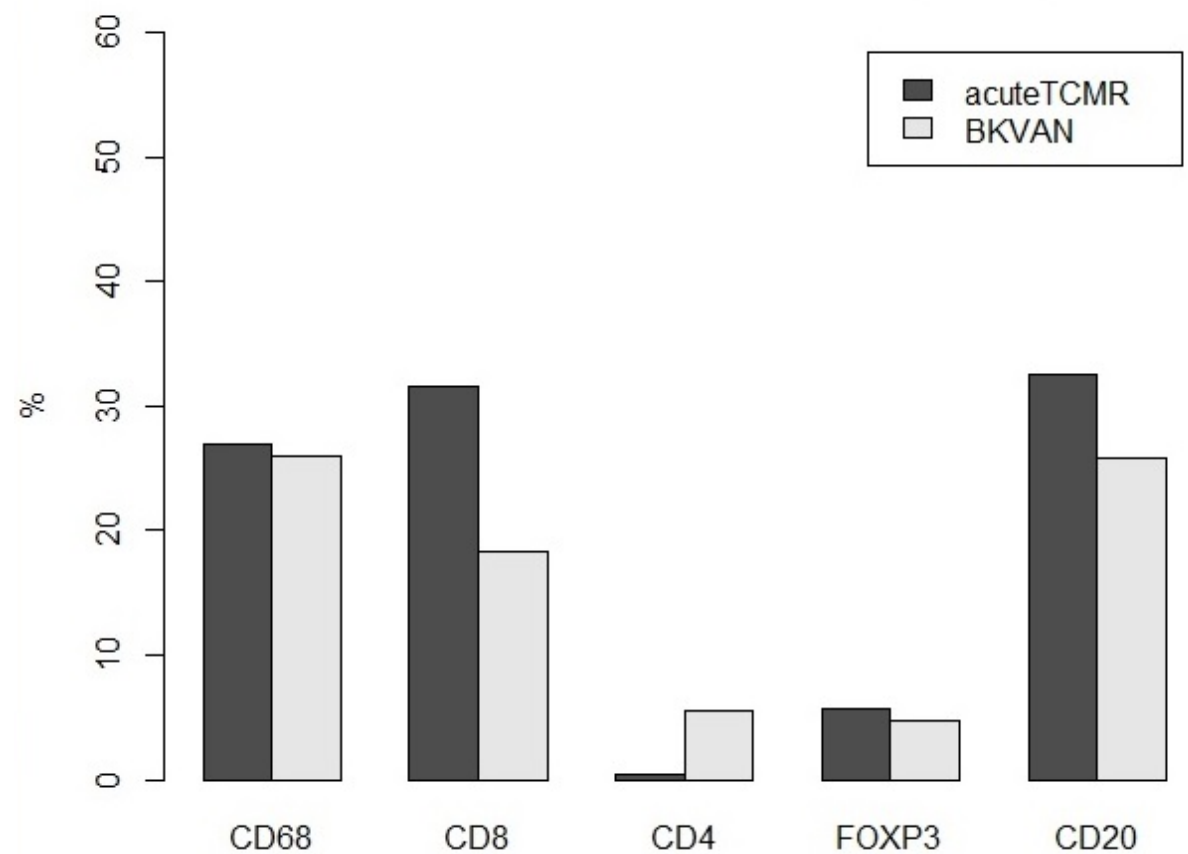

Figure 7. The proportions of mononuclear cell subsets in acute TCMR versus BKVAN cases in the surrounding a large vessel ROI.

\section{Discussion}

The multiplex immunostaining of TCMR samples showed that CD68+ cells were more commonly observed than other types of lymphocytes. Conventional IHC studies have previously suggested this, but we could prove it by using compositional analysis. The allorecognition is the first step in a sequence of complex events that lead to T-cell activation, antibody production, and rejection $[12,13]$. Several studies have demonstrated the predominant occurrence of monocytes/macrophages, in addition to $\mathrm{T}$ cells, using more advanced immunohistochemistry in TCMR cases [14-17]. Girlanda et al. [18] previously demonstrated that a large number of infiltrating monocytes was associated with renal dysfunction. High levels of monocyte infiltration in rejecting allografts have been linked to severe rejection, and glomerular monocyte infiltration has been suggested as an indicator of poor grafting outcomes $[19,20]$. Therefore, IHC monocyte and T-cell percentile measurements may be useful in the assessment of acute clinical findings, especially graft biopsies. Consequently, the macrophage targeting agents have been considered a rejection therapeutic option for improving outcomes for transplant recipients [21,22].

The medulla has been considered as the least specific region for rejection-induced injury. Medullary inflammation may be associated with different diseases, including pyelonephritis and interstitial nephritis [23,24]. However, Wang et al. [25] suggested that medullary inflammation should not rule out a rejection, because medullary inflammation may be a "spillover effect" of cortical lesions, and the medulla has a lower rejection sensitivity (approximately 77\% of that in the cortex). Sis et al. [23] insisted that acute rejection-related lesions are more common and severe in the cortex, while the renal medulla does not sufficiently reflect the inflammation associated with cortical rejection. The positive and negative indicators of inflammatory change in the medulla during the allograft rejection are insufficient as possible predictors. We also tested the composition of infiltrating leukocyte subsets in medulla and medullary rays in acute TCMR cases. Infiltrating leukocyte subsets have well-defined anatomic structures consisting of bundles of renal tubules. The bundles are formed in the renal cortex and continue to run through the renal medulla. In the medullary rays, the most frequently observed cells were CD8+ (38.2\%), followed by CD68+(21.2\%), CD20+(21\%), Foxp3, and CD4+ cells. In the medulla, the most frequently 
observed cells were CD8+ (41.2\%), followed by CD68+ (36.8\%), CD20+ (11.3\%), Foxp3, and CD4+ cells. The prevalence of CD68+ cells was significantly different across the cortical interstitium $(41.8 \%)$, medulla $(36.8 \%)$, medullary ray $(21.2 \%)$, and area surrounding a large vessel $(26.9 \%)$ ROIs ( $p=0.0165$; Table 3 and Figure 4$)$. Moreover, the proportions of CD20+ cells were significantly different between the medulla $(11.3 \%)$ and medullary ray $(21.0 \%)$ areas ( $p=0.0024$; Table 3 and Figure 4). In the medullary ray area, a significant difference was found between then proportions of mononuclear cell subsets found in the medulla and cortical interstitium. Our results demonstrate that medullary ray is an important histologic area. Because medullary rays are located in the cortex, this structure has been identified as a reliable area for inflammation-linked diagnoses and estimation of infiltration intensity using Banff scores. Our results suggest that it is necessary to assess the proportion of medullary ray inflammation on the Banff score chart, especially if the proportion is larger than usual in biopsy specimens.

BKVAN diagnosis has been derived from histological assessments of lymphocytic interstitial infiltrates and the nuclear reaction to the anti-SV-40 antibody-a marker of viral replication [2,7]. Notably, BKVAN diagnosis is difficult to differentiate from acute TCMR. Our data indicate that mononuclear cell subsets in BKVAN samples differ from those of acute TCMR. In the cortical interstitium, CD8+ cells were significantly more prevalent in acute TCMR cases compared to BKVAN cases (34\% vs. 22.8\%, $p=0.034$; Table 3 and Figure 6). In the medulla, CD20+ cells were significantly more prevalent in BKVAN cases compared to acute TCMR cases (51.9\% vs. $11.3 \%, p=0.028$; Table 3$)$. However, further investigation is required to confirm the differences between the two diagnoses using the multiplex immunohistochemistry method.

According to the 1997 Banff guidelines update, assessment areas that should be excluded from Banff lesion scoring include "fibrotic areas, immediate subcapsular cortex, adventitia around large veins, and lymphatics" [1,3,6,7]. However, differences between inflammatory cell subsets in those, and in non-scarred cortical areas, were not investigated. We detected differences in cell subset composition in areas near large vessels $(n=16)$ from the cortical interstitium in acute TCMR cases. CD20+ cells (32.6\%) were the most frequently observed mononuclear cells, although were not associated with acute TCMR effects. We also counted mononuclear cells in the subcapsular area $(n=3)$. Although CD20+ cells were the dominant subset in all these areas, the results were not statistically significant due to the insufficient number of samples.

In summary, this multiplex immunofluorescence assay was a useful method for analyzing mononuclear cell subsets in a renal allograft biopsy. The most frequently observed cells in the cortical interstitium of acute TCMR cases were CD68+ macrophages or monocytes rather than T cells. These cells may contribute to allograft damage in the course of rejection. Although it was difficult to distinguish between BKVAN and acute TCMR by using multiplex immunofluorescence assays, the ratio of CD8+ cells was higher in acute TCMR compared to of BKVAN cases in cortical interstitium (34\% vs. 22.8\%, $p=0.034)$. In the medulla, the assay showed a significantly higher proportions of CD20+ cells in BKVAN cases compared to acute TCMR cases (51.9\% vs. 11.3\%, $p=0.028)$ However, the cellular proportions may be influenced by many factors, e.g., differences in graft age, patient age, and individual differences in immune regimens or doses during the whole clinical course. Further studies that observe change over time in the same patient after applying this method to the protocol biopsy will be important. In areas surrounding large vessels, previously thought of as non-diagnostic, the CD20+ cells were dominant. In the medullary rays, cellular subsets were similar to those of the medulla despite being located in the cortex. Therefore, if cellular infiltration in the medullary rays is high or the medullary ray area occupies a lot of the cortical area, Banff " $\mathrm{i}$ " scoring should be carried out more carefully given our finding that cellular proportions in the medullary ray were different from those in the renal cortical interstitium. 
Author Contributions: Y.-J.K. (Yong-Jin Kim): conceptual and experimental design and paper writing. M.-S.K.: sample collection, ROI selection, and data analysis. J.-H.L.: data analysis. M.-H.H.: data analysis. S.-Y.K.: MIF staining and data analysis. Y.J.K. (Yun Jae Kim): MIF staining and data analysis. All authors have read and agreed to the published version of the manuscript.

Funding: This research was funded by the Biomedical Research Institute grant from Kyungpook National University Hospital (2017).

Institutional Review Board Statement: The study was conducted according to the guidelines of the Declaration of Helsinki and approved by the Daegu Joint Institutional Review Board (DGIRB 2017-08-001, approval date 21 August 2017).

Informed Consent Statement: Patient consent was waived by the Daegu Joint Institutional Review Board.

Conflicts of Interest: The authors declare no conflict of interest.

\section{References}

1. Racusen, L.C.; Solez, K. The Banff 97 working classification of renal allograft pathology. Kidney Int. 1999, 55, 713-723. [CrossRef]

2. Hirsch, H.H.; Brennan, D.C. Polyomavirus-associated nephropathy in renal transplantation: Interdisciplinary analyses and recommendations. Transplantation 2005, 79, 1277-1286. [CrossRef]

3. Loupy, A.; Haas, M. The Banff 2015 Kidney Meeting Report: Current Challenges in Rejection Classification and Prospects for Adopting Molecular Pathology. Am. J. Transplant. 2017, 17, 28-41. [CrossRef]

4. Platt, J.L.; LeBien, T.W. Interstitial mononuclear cell populations in renal graft rejection. Identification by monoclonal antibodies in tissue sections. J. Exp. Med. 1982, 155, 17-30. [CrossRef]

5. Kolbeck, P.C.; Tatum, A.H. Relationships among the histologic pattern, intensity, and phenotypes of T cells infiltrating renal allografts. Transplantation 1984, 38, 709-713. [CrossRef]

6. Sako, H.; Nakane, Y. Immunohistochemical study of the cells infiltrating human renal allografts by the ABC and the IGSS method using monoclonal antibodies. Transplantation 1987, 44, 43-50.

7. Waltzer, W.C.; Miller, F. Immunohistologic analysis of human renal allograft dysfunction. Transplantation 1987, 43, 100-105. [CrossRef]

8. Hofman, P.; Badoual, C. Multiplexed Immunohistochemistry for Molecular and Immune Profiling in Lung Cancer-Just About Ready for Prime-Time? Cancers 2019, 11, 283. [CrossRef]

9. Mani, N.L.; Schalper, K.A. Quantitative assessment of the spatial heterogeneity of tumor-infiltrating lymphocytes in breast cancer. Breast Cancer Res. 2016, 18, 78. [CrossRef]

10. Haas, M.; Loupy, A. The Banff 2017 Kidney Meeting Report: Revised diagnostic criteria for chronic active T cell-mediated rejection, antibody-mediated rejection, and prospects for integrative endpoints for next-generation clinical trials. Am. J. Transplant. 2018, 18, 293-307. [CrossRef]

11. Nickeleit, V.; Singh, H.K. The Banff Working Group Classification of Definitive Polyomavirus Nephropathy: Morphologic Definitions and Clinical Correlations. J. Am. Soc. Nephrol. 2018, 29, 680-693. [CrossRef] [PubMed]

12. Ponticelli, C. The mechanisms of acute transplant rejection revisited. J. Nephrol. 2012, 25, 150-158. [CrossRef] [PubMed]

13. Whitelegg, A.; Barber, L.D. The structural basis of T-cell allorecognition. Tissue Antigens 2004, 63, 101-108. [CrossRef] [PubMed]

14. Halloran, P.F. Immunosuppressive drugs for kidney transplantation. N. Engl. J. Med. 2004, 351, 2715-2729. [CrossRef]

15. von Willebrand, E.; Häyry, P. Composition and in vitro cytotoxicity of cellular infiltrates in rejecting human kidney allografts. Cell Immunol. 1978, 41, 358-372. [CrossRef]

16. Dy, M.; Debray-Sachs, M. Role of macrophages in allograft rejection. Transplant. Proc. 1979, 11, 811-815. [PubMed]

17. Hancock, W.W.; Thomson, N.M. Composition of interstitial cellular infiltrate identified by monoclonal antibodies in renal biopsies of rejecting human renal allografts. Transplantation 1983, 35, 458-463. [CrossRef]

18. Girlanda, R.; Kleiner, D.E. Monocyte infiltration and kidney allograft dysfunction during acute rejection. Am. J. Transplant. 2008, 8, 600-607. [CrossRef]

19. Magil, A.B. Monocytes/macrophages in renal allograft rejection. Transplant. Rev. 2009, 23, 199-208. [CrossRef]

20. Sablik, K.A.; Jordanova, E.S. Immune Cell Infiltrate in Chronic-Active Antibody-Mediated Rejection. Front. Immunol. 2020, 10, 3106. [CrossRef]

21. Li, J.; Li, C. The Evolving Roles of Macrophages in Organ Transplantation. J. Immunol. Res. 2019, 2019, 5763430. [CrossRef] [PubMed]

22. Kopecky, B.J.; Frye, C. Role of donor macrophages after heart and lung transplantation. Am. J. Transplant. 2020, 20 , 1225-1235. [CrossRef] [PubMed]

23. Sis, B.; Sarioglu, S. Renal medullary changes in renal allograft recipients with raised serum creatinine. J. Clin. Pathol. 2006, 59, 377-381. [CrossRef] [PubMed] 
24. Bonsib, S.M.; Reznicek, M.J. Renal medulla in the diagnosis of acute cellular rejection. Transplantation 1989, 48, 690-692. [PubMed]

25. Wang, H.; Nanra, R.S. The renal medulla in acute renal allograft rejection: Comparison with renal cortex. Nephrol. Dial. Transplant. 1995, 10, 1428-1431. 